\title{
Exotic, frothy xenoliths in recent and historical ocean island eruptions
}

Jägerup, S. B. ${ }^{1,2}$, Troll, V. R. ${ }^{2}$, DeEgan, F. M. ${ }^{2}$, GEIGER H. ${ }^{2}$, CARRACEDO, J. C. ${ }^{3}$, HARRIS, C. ${ }^{4}$, VAN DER ZWAN, F. M. ${ }^{1}$ \& ZACZEK, K. ${ }^{2}$

${ }^{1}$ King Abdullah University of Science and Technology, Thuwal, KSA

${ }^{2}$ Department of Earth Science, Uppsala University, Uppsala, Sweden

${ }^{3}$ Universidad de Las Palmas de Gran Canaria, Las Palmas de Gran Canaria, Spain

${ }^{4}$ University of Cape Town, Rondebosch, South Africa

Ocean island volcanism is typically considered a key to unlock mantle processes, but there are a number of notable exceptions. For instance, frothy, felsic xenoliths (referred to as 'xenopumice') are probably derived from the oceanic crust and intrusive portion of ocean islands and shed light on crustal processes. Here, we present oxygen isotope data on a suite of xenopumices erupted by the explosive events of the pre-historic eruption of Las Indias and the 1949 eruption of Cumbre Vieja, La Palma, Canary Islands. For comparison, phonolites and phonolitic xenoliths were sampled from the 1585 Jedey eruption, also on La Palma.

The samples from Las Indias and two samples from the 1949 eruption are quartz-bearing and have high silica content (64 to $74 \mathrm{SiO}_{2}$ wt. \%) and high $\delta^{18} \mathrm{O}$ values (11.1 to $18.3 \%$ ) similar to siliciclastic sedimentary rock. The remaining samples from the 1949 eruption are comprised mainly of alkali feldspars showing $120^{\circ}$ grain boundaries, and they have overall lower silica content (50 to $64 \mathrm{SiO}_{2}$ wt. \%) and $\delta^{18} \mathrm{O}$ values (3.4 to $11.7 \%$ ), consistent with a magmatic rather than sedimentary origin. REE patterns furthermore display a similar compositional spectrum for all quartz-bearing xenopumice, similar to the average REE content of continental crust. The quartz-bearing xenopumice are thus of sedimentary origin, while the feldspar-rich samples reflect primarily plutonic igneous rocks from the island interior. Most of the frothy phonolitic xenoliths and phonolites from the 1585 Jedey eruption have $\delta^{18} \mathrm{O}$ values between 6.7 to 8.3 $\%$.

The frothy texture of the xenopumice implies substantial degassing and expansion of up to $34 \%$ in the magmatic conduit. Such gas release may have profound effects on eruptive mechanisms and might offer an explanation for so far unexplained explosive eruption styles in the Canary Islands, whereby otherwise calm, mafic eruptions can rapidly become explosive in nature. 